\title{
UNDERSTANDING THE COUNSELOR'S COMPETENCE IN GUIDANCE AND COUNSELING SERVICES WITH INCLUSIVE PERSPECTIVE
}

\author{
Hayatul Khairul Rahmat' ${ }^{1}$, Ela Nurmalasari², Lina Dwi Puryanti ${ }^{3}$, \\ Muhammad Syifa'ussurur ${ }^{4}$ \\ ${ }^{1}$ Master Program of Disaster Management, Faculty of National Security, Indonesia Defense University \\ 2,3,4 Master Program of Guidance and Counseling, Postgraduate School, State University, Yogyakarta \\ 1hayatul.rahmat@idu.ac.id, 2elanurmalasari.2020@student.uny.ac.id, \\ 3linadwi.2020@student.uny.ac.id, 4muhammadsyifaussurur.2020@student.uny.ac.id
}

\begin{abstract}
This study aims to explain the competence of counselors in inclusive guidance and counseling services and guidance and counseling services with an inclusive perspective for persons with disabilities. This paper uses a literature approach. Library research is one type of research that uses literature as the object of research. The analysis technique uses content analysis techniques. The results of this study are: (1) the competence of counselors in guidance and counseling services with an inclusive perspective, namely with respect to personal competences, core competencies, and supporting competencies; and (2) guidance and counseling services with inclusive perspective, consisting of academic guidance services, career guidance services, and personal-social guidance services.
\end{abstract}

Keywords: Counselor competence; guidance and counseling services, inclusive education.

Abstrak: Tulisan ini bertujuan untuk menjelaskan tentang kompetensi konselor dalam layanan bimbingan dan konseling berwawasan inklusif serta layanan bimbingan konseling yang berwawasan inklusif pada penyandang disabilitas. Tulisan ini menggunakan pendekatan kepustakaan. Penelitian kepustakaan adalah salah satu jenis penelitian yang menggunakan literatur sebagai objek penelitian. Adapun teknik analisis menggunakan teknik analisis konten. Hasil dari penelitian ini adalah (1) kompetensi konselor dalam layanan bimbingan dan konseling berwawasan inklusif yaitu berkenaan dengan kompetensi pribadi, kompetensi inti, dan kompetensi pendukung, serta (2) layanan bimbingan konseling yang berwawasan inklusif terdiri dari layanan bimbingan akademik, layanan bimbingan karier, dan layanan bimbingan pribadi-sosial.

Kata Kunci: Kompetensi konselor; layanan bimbingan konseling; pendidikan inklusif.

\section{A. Introduction}

Education was a basic need of every human being to ensure his survival to be more dignified. Therefore, the state had an obligation to provide quality educational services to every citizen without exception including persons with disabilities as stated in the 1945 Constitution of the Republic of Indonesia. ${ }^{1}$ Unfortunately, the education system in Indonesia had not accommodated diversity, resulting in the emergence of segmentation of educational institutions which was based on differences in religion, ethnicity, and even differences in the physical and

\footnotetext{
${ }^{1}$ Abror Sodik, "Konseling sebagai Suatu Sistem Pendidikan Sekolah," Hisbah: Jurnal Bimbingan Konseling dan Dakwah Islam 13, no. 1 (2016): 1-17, https://doi.org/10.14421/hisbah.2016.131.01.
} 
mental abilities of students. This segmentation of educational institutions had clearly prevented students from learning to respect the reality of diversity in society. ${ }^{2}$

The Law Number 20 of 2013 concerning the National Education System opened the way for children with disabilities to be able to get an education properly. Inclusive education was specifically defined as an effort to provide education for children with disabilities and normal children to learn. With the existence of inclusive education, it means that the school must be able to accommodate every child without exception, physically, intellectually, emotionally, socially, language, culture, ethnicity, minority and various other things. The goal is that there are no gaps between children with disabilities and other normal children. It is also hoped that children with disabilities can maximize their potential. ${ }^{3}$

Inclusive education was not something new in the world of education. Inclusive education began in 1990 with the holding of the World Conference on Education for All in Thailand which resulted in all children being able to go to school and be provided with education according to their needs. ${ }^{4}$ Fulfilling the needs of children with disabilities certainly required changes from various aspects both the education system, methods, and the environment. The goal was for children with disabilities need to be able to adjust. In order to optimize education for children with disabilities, in addition to the role of the school as an education delivery unit, teachers, the community, and parents, and the role of guidance and counseling is also very helpful in achieving an educational goal. ${ }^{5}$

Guidance and counseling was considered to have positive values and contribute a lot in helping to achieve learning goals for children with disabilities. There was where the importance of counseling for children with disabilities. Every school needs a guidance and counseling teacher who specifically handles children with disabilities, both in inclusive education and special education. Due to the lack of the maximum need for guidance and counseling, it cannot be denied that the development of the abilities and competencies of each student will be lacking. Even though there are so many children with disabilities who have shown their talents through competitions in various regions, and have reaped brilliant results. This is just one example of the many children with disabilities who are brilliant. With the support of guidance and counseling services, their achievement and talent development will be more assisted.

In supporting the achievement of guidance and counseling needs for children with disabilities, it is very important a competency that every guidance and counseling teacher or counselor must have in providing guidance and counseling services to students with disabilities. ${ }^{6}$ Therefore, the authors are interested to explain the competencies that a counselor must have in providing guidance and counseling services with inclusive perspective and to explain guidance and counseling services with inclusive perspective provided to student with disabilities.

\footnotetext{
2 Eka Sari Setianingsih, "Layanan Bimbingan dan Konseling bagi Anak Berkebutuhan Khusus Melalui Pendekatan Islam di Kelas Inklusi," Konseling Edukasi: Journal of Guidance and Counseling 2, no. 2 (2018): $1-24$.

${ }^{3}$ Muhammad Awwad, "Urgensi Layanan Bimbingan dan Konseling bagi Anak Berkebutuhan Khusus," AlTazkiah: Jurnal Bimbingan dan Konseling Islam 4, no. 1 (2015): 46-64.

${ }^{4}$ Lutfi Isni Badiah, "Urgensi Bimbingan dan Konseling Bagi Anak Berkebutuhan Khusus (ABK) di Sekolah Inklusi," Seminar Nasional Bimbingan Konseling Universitas Ahmad Dahlan (2017): 123-131, http://seminar.uad.ac.id/index.php/snbkuad/article/view/68.

${ }^{5}$ Abd. Kadir, "Penyelenggaraan Sekolah Inklusi di Indonesia," Jurnal Pendidikan Agama Islam 03, no. 01 (2015): 2-22.

6 Ulya Makhmudah, "Mempersiapkan Kompetensi Kepribadian Calon Konselor untuk Menghadapi Masyarakat Ekonomi ASEAN," Jurnal Psikoedukasi dan Konseling 1, no. 1 (2017): 68-76, https://dx.doi.org/10.20961/jpk.v1i1.11462.
} 


\section{B. Methods}

In the preparation of this paper used the library research method, which is to collect all reading material related to the issues discussed, then understand carefully and carefully so as to produce research findings. ${ }^{7}$ To supporting this research, the authors conducted an in-depth literature study by using descriptive writing. ${ }^{9}$ Descriptive method was a method in examining the status of a group of people, an object, a system of thought, or a class of events in the present. The purpose of descriptive writing was to make descriptions, descriptions or paintings systematically, factually, and accurately regarding the facts, characteristics, and relationships between the phenomena being investigated.10 The data collected in this writing was secondary data, namely the source of writing data obtained indirectly or through intermediary media. Secondary data can generally be in the form of evidence, notes, or historical reports that have been compiled in archives (documentary data), both published and unpublished. In analyzing the data, the writer used the content analysis method, namely the data obtained and then arranged so that it would facilitate the discussion of existing problems.

\section{Results and Discussion}

\section{Introduction to Guidance and Counseling with Inclusive Perspective}

Guidance and counseling with inclusive perspective was activities to help students with disabilities in an effort to find self-concepts, facilitate adjustment to their barriers, coordinate with other experts, conduct counseling with their families, help develop children with disabilities to develop effectively, have independent life skills, and develop hobbies, and develop social and personal skills. ${ }^{11}$ IIn general, the objectives of guidance and counseling must essentially refer to have a meaning, have nuances, and are in tune with the goals of national education. In particular, the purpose of guidance and counseling for children with disabilities must reflect their special needs, help individuals develop themselves optimally according to their developmental stages and predispositions (abilities, talents, interests, problems, and needs), as well as according to their socio-cultural background and positive environmental demands. The objectives of guidance anf counseling for children with disabilities in general include: (a) helping students to be able to pass through each developmental transition well; (b) helping learners in overcoming learning barriers and developmental barriers or problems they face through meeting their particular needs; (c) help prepare the mental development of children to enter higher education levels; and (d) helping students achieve a level of independence and happiness in life. ${ }^{12}$

According to Sunardi ${ }^{13}$, guidance and counseling services for children with disabilities must be based on certain principles. This principle is broadly related to the matters described in the table as follows:

\footnotetext{
7 James Danandjaja, “Metode Penelitian Kepustakaan," Jurnal Antropologi Indonesia 52 (1997), https://doi.org/10.7454/ai.v0i52.3318.

8 Mestika Zed, Metode Penelitian Kepustakaan (Jakarta: Yayasan Obor Indonesia, 2002).

${ }_{9}^{9}$ Agung Priambodo, Nrangwesthi Widyaningrum, and Hayatul Khairul Rahmat, "Strategi Komando Resor Militer 043/ Garuda Hitam dalam Penanggulangan Bencana Alam di Provinsi Lampung," Perspektif 9, no. 2 (2020): 307-313.

10 Hayatul Khairul Rahmat, "Mobile Learning Berbasis Appypie sebagai Inovasi Media Pendidikan untuk Digital Natives dalam Perspektif Islam," Tarbawi: Jurnal Pendidikan Islam 16, no. 1 (2019): 33-50, https://doi.org/10.34001/tarbawi.v1i1.999.

11 Desje Lattu, "Peran Guru Bimbingan dan Konseling pada Sekolah Penyelenggara Pendidikan Inklusi," Jurnal Bimbingan dan Konseling Terapan 2, no. 1 (2018): 61-67.

12 Edi Purwanta, "Kompetensi Konselor dalam Menghadapi Pendidikan Inklusi," in Konvensi Nasional XIV dan Kongres X Asosiasi Bimbingan Konseling Indonesia (Semarang, 2005).

13 Sunardi, Pedoman Pelaksanaan BP di SLB (Bandung: Jurusan Pendidikan Luar Biasa Fakultas Ilmu Pendidikan Universitas Pendidikan Indonesia, 2005).
} 
Table 1. Principles of Counseling Guidance Services for Students with Disabilities

\begin{tabular}{|c|c|c|}
\hline No. & Principles & Explanation \\
\hline 1 & $\begin{array}{l}\text { Targeted Guidance } \\
\text { Services }\end{array}$ & $\begin{array}{l}\text { a. Guidance is aimed at all individuals with disabilities } \\
\text { regardless of age, ethnicity, religion and socioeconomic } \\
\text { status. } \\
\text { b. Coaching deals with strange and unique individuals. } \\
\text { c. Guidance is fully concerned with the stages and various } \\
\text { aspects of individual development that is different. } \\
\text { d. Coaching gives primary attention to the differences of the } \\
\text { different individuals on which it is served. }\end{array}$ \\
\hline 2 & Individual Problems & $\begin{array}{l}\text { The problems faced by individuals are complex, as far as } \\
\text { possible minimized, therefore in guidance services it is } \\
\text { necessary to involve parents, schools, and the community. }\end{array}$ \\
\hline 3 & $\begin{array}{l}\text { Guidance Service } \\
\text { Program }\end{array}$ & $\begin{array}{l}\text { a. Guidance services are an integral part of individual } \\
\text { education and development so guidance programs must be } \\
\text { tailored and integrated with the education program and } \\
\text { student development. } \\
\text { b. The mentorship program must be flexible, tailored to the } \\
\text { needs of the individual, society, and institutional conditions. } \\
\text { c. The guidance program is arranged from the lowest to the } \\
\text { highest level of education. } \\
\text { d. Regarding the content and implementation of the guidance } \\
\text { program there needs to be regular assessment activities and } \\
\text { directed. }\end{array}$ \\
\hline 4 & $\begin{array}{l}\text { Implementation of } \\
\text { Guidance Services }\end{array}$ & $\begin{array}{l}\text { a. Guidance should be directed towards the development of } \\
\text { ultimately capable individuals guide yourself in dealing with } \\
\text { problems. } \\
\text { b. In the process of guiding decisions taken by individuals } \\
\text { should be on a whim the individual himself, not at the } \\
\text { request or insistence of the mentor. } \\
\text { c. Collaboration between tutors, teachers, parents, and a team } \\
\text { of experts will determine the results guidance service. } \\
\text { d. The development of the guidance service program is } \\
\text { pursued through direct utilization maximum assessment } \\
\text { results. } \\
\text { e. The results of the implementation of guidance should be } \\
\text { followed up with evaluation activities and follow-up. }\end{array}$ \\
\hline
\end{tabular}

\section{Understanding the Counselor's Competence in Giving Guidance and Counseling Services with Inclusive Perspective}

A complete counselor was a counselor who has competence according to predetermined standards. As is common in a profession, the full figure of the counselor consists of two distinct components. ${ }^{14}$ However, these components are integrated into each other in praxis, so that they cannot be separated. According to the Indonesian Guidance and Counseling Association (ABKIN), there are two complete competencies for counselors, namely having academic competence and professional competence. ${ }^{15}$ First, academic competence. Academic competencies required for

\footnotetext{
${ }^{14}$ Hesty Nurrahmi, "Kompetensi Profesional Guru Bimbingan dan Konseling," Al-Hikmah: Jurnal Dakwah 9, no. 1 (2015): 45-55, https://doi.org/1.24260/al-hikmah.v9i1.87.

${ }^{15}$ ABKIN, Penataan Pendidikan Profesional Konselor dan Layanan Bimbingan dan Konseling dalam Jalur Pendidikan Formal (Jakarta: Departemen Pendidikan Nasional, 2018).
} 
prospective counselors include the ability: (a) to know the counselee in depth, which is indicated by the presence of empathy, tolerance and prioritizing the benefit of the counselee; (2) mastering the scientific repertoire of guidance and counseling; and (c) developing professionalism as a counselor on an ongoing basis which will be a requirement for achieving the counselor's professional competence. Second, professional competence. After the counselor's academic competence has been taken when the undergraduate is mastered, the counselor can further participate in more systematic activities in the field to achieve professional competence. The professional competence means that the counselor participates in the counselor's professional education program (Program Profesi Konselor). As a vehicle for laying the foundation of abilities and habits to develop professionalism in a sustainable manner, the professional counselor education is ideally pursued by professional counselors.

Providing guidance and counseling with inclusive perspective must be supported by the competence of the counselor in providing services to the counselee. Academic competence and professional competence possessed by the counselor are considered inclusive if they are able to provide comprehensive services and are able to accept the counselee without conditions. Guidance and counseling services are expected to be able to provide counselees with disabilities. In helping counselees with disabilities, it is hoped that the counselor will be able to provide services according to the counselee's needs. The demand for this ability is implied in the counselor's competence which is expressed in the characteristics of his professionalism. According to Furqan in Murad ${ }^{16}$, at least these competencies are summarized in three points of study, namely personal competencies, core competencies, and supporting competencies.

Firstly, personal competence. Personal competence refers to the counselor's personal qualities with regard to the ability to build healthy good relationships, work ethic, professional commitment, ethical and moral foundation in behavior, drive and enthusiasm for selfdevelopment, and the ability to do problem solving. Secondly, core competencies. Core competencies are direct abilities to manage and provide guidance services starting with mastery of the basic concepts and theories of guidance and counseling, organizing various kinds of guidance services in various settings and managerial abilities. Thirdly, supporting competencies. Supporting competencies are additional abilities that are expected to strengthen or strengthen the counselor's adaptability. Based on these three competencies, at least nine aspects of the counselor's professional performance can be developed, namely: (1) interpersonal relationships; (2) work ethic and professional commitment; (3) ethical and moral behavior; (4) encouragement and selfdevelopment efforts; (5) problem solving and adjustment skills; (6) efforts to provide assistance to students; (7) management guidance and counseling in schools; (8) guidance instrumentation; and (9) providing guidance services.

According to Purwanta ${ }^{17}$, there are seven minimum competencies that must be mastered by a counselor, the seven competencies are: (1) mastering educational concepts and praxis; (2) having awareness and commitment to professional ethics; (3) mastering the concept of individual behavior and development; (4) mastering assessment concepts and praxis; (5) mastering the concepts and practice of guidance and counseling; (6) having the ability to manage guidance and counseling programs; and (7) mastering research concepts and praxis in guidance and counseling. In order to welcome the implementation of inclusive education in Indonesia, the competency standards mentioned above should be controlled more by counselors. In addition, additional competencies related to understanding individual behavior in the context of togetherness between diffable and non-disabled counselees are also important. So that the provision of guidance and counseling services can be provided as a whole, without comparing counselees with one another. The focus of providing guidance and counseling services to assist the counselee in achieving independence needs to be adjusted to the needs of

\footnotetext{
${ }^{16}$ Abduk Murad, "Profil Konselor Standar," in Konvensi Nasional XIII Bimbingan dan Konseling (Bandung, 2003).

17 Purwanta, "Kompetensi Konselor dalam Menghadapi Pendidikan Inklusi."
} 
the counselee in achieving his developmental tasks. As for practice in the field, counselors who already have competency standards as listed above can work together with special assistant teachers in providing services. In line with the opinion of Hermanto in Badiah ${ }^{18}$, in assisting students with disabilities, counselors in inclusive schools was expected to have several competencies, namely: competence in implementing new student admissions that accommodate all children; competence in implementing a flexible and accommodating curriculum; competence in designing teaching materials, teaching and learning activities and organizing child-friendly classes; and competence in procuring adaptive media use, and conducting learning evaluations in inclusive education settings.

\section{Guidance and Counseling Services with Inclusive Perspective: A Compehensive Exploration}

Guidance and counseling services are the process of providing assistance to students in order to achieve independence and self-understanding, so that students are able to direct themselves according to their developmental tasks in the school, family and community environment. ${ }^{19}$ Guidance and counseling services with inclusive perspective can be interpreted as activities that help students with disabilities to find their own concept, provide facilities for adjustment to the barriers they have, coordinate with other experts and conduct family counseling with the aim that students are able to develop effectively, have independence, develop hobbies and personal social skills. ${ }^{20}$ In guidance and counseling services with inclusive perspective, there are several services, namely academic guidance services, career guidance services, and personal-social guidance services. ${ }^{21}$ This can be described as follows:

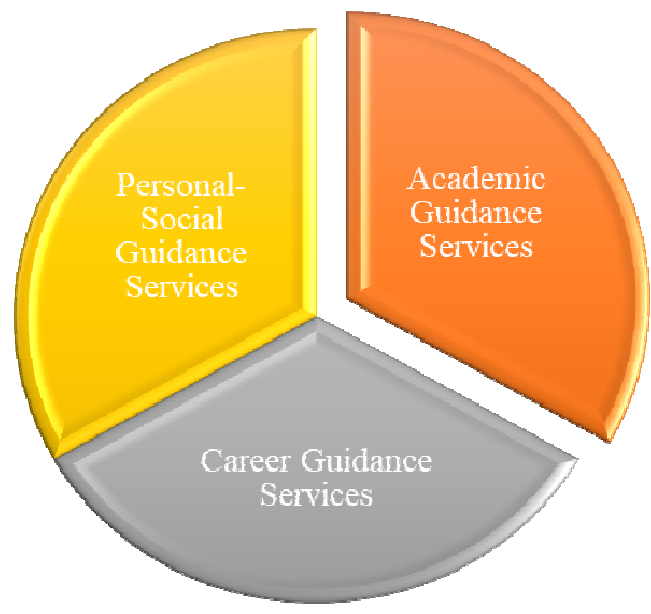

Figure 1. Guidance and Counseling Services for Student with Disabilities

Based on Figure 1 above, guidance and counseling services for student with disabilities can be explains as follow. First, academic guidance services. Academic guidance or what is commonly referred to as tutoring in general aims so that students are able to develop optimally

\footnotetext{
${ }^{18}$ Badiah, "Urgensi Bimbingan dan Konseling bagi Anak Berkebutuhan Khusus (ABK) di Sekolah Inklusi."

${ }^{19}$ Keke T. Aritonang, "Minat dan Motivasi dalam Meningkatkan Hasil Belajar Siswa," Teachers College Record 115, no. 10 (2013): 10-21.

${ }^{20}$ Lattu, "Peran Guru Bimbingan dan Konseling pada Sekolah Penyelenggara Pendidikan Inklusi."

${ }^{21}$ Hayatul Khairul Rahmat, "Implementasi Strategi Layanan Bimbingan dan Konseling Komprehensif bagi Siswa Tunanetra di MTs Yaketunis Yogyakarta," Hisbah: Jurnal Bimbingan Konseling dan Dakwah Islam 16, no. 1 (2019): 37-46, https://doi.org/10.14421/hisbah.2019.161-03.
} 
in the academic field and be able to solve various learning problems. According to Tohirin ${ }^{22}$, there are four aspects that require guidance and counseling services, namely: introduction to the curriculum, selection of majors, appropriate learning methods, and educational planning. In inclusive-based academic guidance services, a multiple intelligence system needs to be applied. This multiple intelligence system assumes that teachers need to have a paradigm of "Bury the shortcomings of our students, develop the strengths of our students". This means that in this academic service, teachers focus on the abilities/ strengths of students. Basically, every student, either with disabilities or does not have advantages or disadvantages. For this reason, in this academic guidance service, besides being adjusted to the needs of students, it is also adjusted to the abilities of each student. ${ }^{23}$

Second, career guidance services. Career guidance services are services provided with the aim that students are able to identify and develop their potential, plan for the future and choose the right career according to their abilities after completing education. According to Tohirin ${ }^{24}$, this career guidance service does not help students in a career, but this service is informative. Comprehensive information about the career world will reduce students' barriers in making decisions. However, information alone is not enough, it must be followed up with full guidance and mentoring so that students are able to recognize their potential (talents and interests) as well as their own shortcomings and weaknesses which are then adjusted to their career planning and decision making. ${ }^{25}$ In inclusion-based career guidance services, guidance activities are tailored to the abilities of each student.

Third, personal-social guidance services. Social personal guidance services are services provided to students with the aim that students are able to solve their personal social problems. ${ }^{26}$ This service is considered effective in increasing the ability of students to adjust themselves. This is because this service focuses on optimizing skills in social relationships. In children, special needs with deficiencies often make students less confident. For this reason, this form of personal social guidance service is to grow and increase the self-confidence of students. This self-confidence is also the provision for students to socialize well.

\section{Conclusion}

Guidance and counseling services in an inclusive setting aim to assist students in achieving optimal development according to their level and type of excellence. A child with special needs is said to have succeeded in achieving optimal development if he can use his remaining abilities optimally according to the degree of disability. In this case, the role of a counselor is very important to make it happen and is supported by the competencies that the counselor needs to have, which consists of personal competences, core competencies and supporting competencies. This competency will be very helpful in providing counseling services with an inclusive perspective consisting of academic guidance services, career guidance services, and personalsocial guidance services.

\footnotetext{
22 Tohirin, Bimbingan Dan Konseling di Sekolah dan Madrasah (Berbasis Integrasi) (Jakarta: Raja Grafindo Persada, 2007).

${ }^{23}$ Arie Supriyatno and Tawil, "Pendampingan Pelaksanaan Bimbingan Belajar Berbasis Multiple Intelligence untuk ABK di SDM 2/MIM Kota Magelang," Journal of Innnovative Counseling: Theory, Practice \& Research 2, no. 2 (2019): 10-15, https://journal.umtas.ac.id/index.php/innovative_counseling/article/view/249.

${ }^{24}$ Tohirin, Bimbingan dan Konseling di Sekolah dan Madrasah (Berbasis Integrasi).

${ }^{25}$ Richma Hidayati, "Layanan Informasi Karir Membantu Peserta Didik dalam Meningkatkan Pemahaman Karir," Jurnal Konseling Gusjigang 1, no. 1 (2015), https://doi.org/10.24176/jkg.v1i1.258.

26 Ana Rafikayati, Lutfi Isni Badiah, and Boy Soedarmadji, "Pengaruh Implementasi Layanan Bimbingan Pribadi Sosial terhadap Penyesuaian Diri Anak Berkebutuhan Khusus (ABK) di Sekolah Inklusi SMAN 10 Surabaya," Buana Pendidikan : Jurnal Fakultas Keguruan dan Ilmu Pendidikan 14, no. 26 (2018): 151-157.
} 


\section{References}

ABKIN. Penataan Pendidikan Profesional Konselor Dan Layanan Bimbingan Dan Konseling Dalam Jalur Pendidikan Formal. Jakarta: Departemen Pendidikan Nasional, 2018.

Aritonang, Keke T. "Minat Dan Motivasi Dalam Meningkatkan Hasil Belajar Siswa." Teachers College Record 115, no. 10 (2013): 10-21.

Awwad, Muhammad. "Urgensi Layanan Bimbingan Dan Konseling Bagi Anak Berkebutuhan Khusus." Al-Tazkiah: Jurnal Bimbingan dan Konseling Islam 4, no. 1 (2015): 46-64.

Badiah, Lutfi Isni. "Urgensi Bimbingan Dan Konseling Bagi Anak Berkebutuhan Khusus (ABK) Di Sekolah Inklusi." Seminar Nasional Bimbingan Konseling Universitas Ahmad Dahlan (2017): 123-131. http://seminar.uad.ac.id/index.php/snbkuad/article/view/68.

Danandjaja, James. "Metode Penelitian Kepustakaan.” Jurnal Antropologi Indonesia 52 (1997). https://doi.org/10.7454/ai.v0i52.3318.

Hidayati, Richma. "Layanan Informasi Karir Membantu Peserta Didik Dalam Meningkatkan Pemahaman Karir." Jurnal Konseling Gusjigang 1, no. 1 (2015). https://doi.org/10.24176/jkg.v1i1.258.

Kadir, Abd. "Penyelenggaraan Sekolah Inklusi Di Indonesia." Jurnal Pendidikan Agama Islam 03, no. 01 (2015): 2-22.

Lattu, Desje. "Peran Guru Bimbingan Dan Konseling Pada Sekolah Penyelenggara Pendidikan Inklusi." Jurnal Bimbingan dan Konseling Terapan 2, no. 1 (2018): 61-67.

Makhmudah, Ulya. "Mempersiapkan Kompetensi Kepribadian Calon Konselor Untuk Menghadapi Masyarakat Ekonomi ASEAN." Jurnal Psikoedukasi dan Konseling 1, no. 1 (2017): 68-76. https://dx.doi.org/10.20961/jpk.v1i1.11462.

Murad, Abduk. "Profil Konselor Standar." In Konvensi Nasional XIII Bimbingan Dan Konseling. Bandung, 2003.

Nurrahmi, Hesty. "Kompetensi Profesional Guru Bimbingan Dan Konseling." Al-Hikmah: Jurnal Dakwah 9, no. 1 (2015): 45-55. https://doi.org/1.24260/al-hikmah.v9i1.87.

Priambodo, Agung, Nrangwesthi Widyaningrum, and Hayatul Khairul Rahmat. "Strategi Komando Resor Militer 043/ Garuda Hitam Dalam Penanggulangan Bencana Alam Di Provinsi Lampung." PERSPEKTIF 9, no. 2 (2020): 307-313.

Purwanta, Edi. "Kompetensi Konselor Dalam Menghadapi Pendidikan Inklusi." In Konvensi Nasional XIV Dan Kongres X Asosiasi Bimbingan Konseling Indonesia. Semarang, 2005.

Rafikayati, Ana, Lutfi Isni Badiah, and Boy Soedarmadji. "Pengaruh Implementasi Layanan Bimbingan Pribadi Sosial Terhadap Penyesuaian Diri Anak Berkebutuhan Khusus (ABK) Di Sekolah Inklusi SMAN 10 Surabaya." Buana Pendidikan : Jurnal Fakultas Keguruan dan Ilmu Pendidikan 14, no. 26 (2018): 151-157.

Rahmat, Hayatul Khairul. "Implementasi Strategi Layanan Bimbingan Dan Konseling Komprehensif Bagi Siswa Tunanetra Di MTs Yaketunis Yogyakarta." Hisbah: Jurnal Bimbingan Konseling dan Dakwah Islam 16, no. 1 (2019): 37-46. https://doi.org/10.14421/hisbah.2019.161-03.

- - - "Mobile Learning Berbasis Appypie Sebagai Inovasi Media Pendidikan Untuk Digital Natives Dalam Perspektif Islam." Tarbawi: Jurnal Pendidikan Islam 16, no. 1 (2019): 33-50. https://doi.org/10.34001/tarbawi.v1i1.999.

Setianingsih, Eka Sari. "Layanan Bimbingan Dan Konseling Bagi Anak Berkebutuhan Khusus Melalui Pendekatan Islam Di Kelas Inklusi." Konseling Edukasi: Journal of Guidance and Counseling 2, no. 2 (2018): 1-24. 
Vol. 2 No. 1, 2020

Sodik, Abror. "Konseling Sebagai Suatu Sistem Pendidikan Sekolah." Hisbah: Jurnal Bimbingan Konseling dan Dakwah Islam 13, no. 1 (2016): 1-17. https://doi.org/10.14421/hisbah.2016.131.01.

Sunardi. Pedoman Pelaksanaan BP Di SLB. Bandung: Jurusan Pendidikan Luar Biasa Fakultas Ilmu Pendidikan Universitas Pendidikan Indonesia, 2005.

Supriyatno, Arie, and Tawil. "Pendampingan Pelaksanaan Bimbingan Belajar Berbasis Multiple Intelligence Untuk ABK Di SDM 2/MIM Kota Magelang." Journal of Innnovative Counseling: Theory, Practice \& Research 2, no. 2 (2019): 10-15. https://journal.umtas.ac.id/index.php/innovative_counseling/article/view/249.

Tohirin. Bimbingan Dan Konseling Di Sekolah Dan Madrasah (Berbasis Integrasi). Jakarta: Raja Grafindo Persada, 2007.

Zed, Mestika. Metode Penelitian Kepustakaan. Jakarta: Yayasan Obor Indonesia, 2002. 